\title{
Model of Optimization of Wind Energy Production in the Light of Legal Changes in Poland
}

\author{
Marcin Rabe ${ }^{1}$, Dalia Streimikiene ${ }^{2}(1)$ and Yuriy Bilan ${ }^{3, *(1)}$ \\ 1 Institute of Management, University of Szczecin, 71-004 Szczecin, Poland; marcin.rabe@wzieu.pl \\ 2 Laboratory of Complex Energy Research, Lithuanian Energy Institute, Breslaujos 3, LT-44403 Kaunas, \\ Lithuania; dalia.streimikiene@knf.vu.lt \\ 3 Faculty of Management, Rzeszow University of Technology, 35-959 Rzeszów, Poland \\ * Correspondence: y.bilan@prz.edu.pl
}

Received: 20 February 2020; Accepted: 17 March 2020; Published: 27 March 2020

\begin{abstract}
The article discusses the planning of wind energy development in the West Pomeranian Region after the introduction of the Act "On investments in wind farms" as of 20 May 2016. The purpose of the article is to provide the forecast of the region's wind energy development in 2019-2030 by taking into account current legal regulations in Poland. The article proposes an original, optimizing multi-criteria wind energy development model for the studied region, exploring various types of technologies that may appear in the system, taking into account recent legal and political changes in the field of renewable energy regulation in Poland. The results of the optimization model show that the currently passed Act "On investments in wind farms" in Poland actually stopped the development of wind energy in the region. On the other hand, in accordance with the objectives of the adopted draft of the Polish energy policy until 2040, it is expected that the share of renewable energy in electricity production will increase in 2030 in the studied region. Therefore, the paper argues that policy changes are necessary to meet the renewable energy goals of Poland.
\end{abstract}

Keywords: sustainable energy; wind energy; energy policy; Polish Energy Policy Project until 2040

\section{Introduction}

Energy, among many sectors of the national economy, is a special field, and the products of this sector have a major impact on the smooth functioning of other economic sectors [1,2]. Today's world needs energy; its consumption on the global scale is constantly increasing. On the one hand, this development generates an increase in energy expenditure necessary for the effective operation of all economic sectors. At the same time, it influences the growth of consumption, which is connected with the growing energy consumption in the entire energy production cycle. One of the key problems in this regard is the concentration of the world oil and gas resources in several countries only, and this, in turn, means that investments in mining are often determined, in addition to economic criteria, by political ones [3].

Production and use of electricity cause emission of greenhouse gases (GHG) as well as the devastation of the natural environment, mainly due to gas emissions that arise when fossil fuels are burnt, coal especially [4]. Hence, one of the most serious global problems today is the excessive emission of $\mathrm{CO}_{2}$, which is causing the phenomenon of the greenhouse effect. Changing the above trend, i.e., switching energy production to less-polluting sources, will be very difficult [4]. Mitigating climate change and reducing greenhouse gas (GHG) emissions are important challenges, among others, for the global energy sector. To reduce the emission level, it is necessary to search for and use high-efficiency, economically efficient energy sources, including renewable ones, as well as effective and energy-saving solutions in industries and construction [4-6]. 
Renewable energy sources are becoming an alternative to fossil resources not only because of the exhaustion and growing costs of mining the latter but also because the former is increasingly seen as a way to reduce the process of environmental destruction. Renewable energy sources are understood as the amount of energy that is obtained in constantly renewable natural processes. Appearing in various forms, renewable energy is generated directly or indirectly by solar energy or heat from the Earth's core. The scope of this definition includes energy generated by solar radiation, wind, biomass, geothermal watercourses, and ocean resources, as well as biofuel and hydrogen. Renewable energy sources also perfectly fit into the concept of sustainable development, recognized as a cure for numerous economic, ecological, and social problems [7-14].

Wind energy resources, in accordance with the Energy Law, should be understood as an estimated amount of electricity that can be obtained in a given area for practical purposes [15]. The presence of winds always has an accidental nature. Wind blowing at a speed of no less than $4 \mathrm{~m} / \mathrm{s}$ and no more than $30 \mathrm{~m} / \mathrm{s}$ is considered to be energetically useful for turbine generators of electricity [16]. Wind is a kinetic force moving air masses. The direct factor of wind formation is an irregular configuration of atmospheric pressure over the Earth's surface. The speed of wind, or the movement of air masses, contains a very large charge of energy, which in principle is inexhaustible. All over the world, open-air resources of wind energy are estimated to be approximately 53,000 TWh/year.

Wind energy is inseparably connected with landscape. Wind power plants as high-altitude objects (currently about $200 \mathrm{~m}$ ), with a contrasting colour in relation to the background, and additionally moving, strongly interfere in the landscape. Depending on the design and development of the area, as well as the type and quantity of devices located in one place, wind farms can be seen from a distance of many kilometres. In 2004, Poland ratified the European Landscape Convention (ECC), committing itself to care for the quality of the surrounding space-the landscape. The main parameters enabling the estimation of the size of wind energy resources are wind speed and frequency of repeating individual speeds.

Policies and measures promoting renewable energy development have important impacts on the penetration of renewables, though wind energy development encounters important restraints related to geographical conditions mentioned above [15-22].

The presented article attempts to identify and analyse the conditions related to the implementation of the regional energy policy, with a particular emphasis on the potential for wind energy development in the light of new legal acts and national policies.

The main goal of the article is to build a mathematical model of the regional energy system, taking into account the development potential of wind energy in the West Pomeranian Region, main economic, ecological, and social criteria of sustainable development, and recent changes in the legal acts regulating renewable energy development in Poland.

An important contribution of this article is to offer an energy system optimization model at the level of local government (poviats and communes) and to present recommendations and guidelines on energy policy for local governments in the analysed period. The developed model would allow local government to make informed decisions in the formulation of regional policy in relation to the future production, structure, and specialization of renewable energy by taking into account such issues as land use, current production structure, soil, farm types, choice of technology, work skills and their use, availability of resources. A model that meets the above requirements is an effective tool for long-term least-cost energy system planning at the local level. The main task of the model is to present a simplified but transparent picture of reality, ensuring its use in changing conditions, i.e., taking into account various aspects of the system, although they do not have to occur in all cases. As a result of presenting a simplified picture of reality, 24 decision variables were adopted in the model.

Until now, only a few authors have comprehensively dealt with this issue. There is a lack of comprehensive research on decision models for local renewable energy policies in Polish regions. The paper presents a case study of the West Pomeranian Region, but the same approach can be applied to other regions in Poland and other countries. The undertaken research is a contribution 
to the development of knowledge about regional energy planning and assessment of the prospects of alternative energy sources in a selected region, taking into account environmental and other legal provisions.

The research material for this article was taken from many sources, both domestic and foreign, among others, empirical data from scientific energy and fuel institutes, regional energy institutions. The research has contributed to extended cooperation between such institutions as the Provincial Inspectorate for Environmental Protection, the Marshal's Office of the province West Pomeranian, Enea, Dolna Odra SA Power Plant Complex and Szczecin Power Plant.

\section{Review of Energy Policies in Poland Relevant West Pomeranian Region}

The basic documents for the assessment of development in the field of electrical power engineering in Poland are the applicable EU documents and directives as well as government documents and Polish legal regulations, the most important of which is the Energy Policy of Poland until 2030, the Act of 10.04.1997 Energy Law (Official Journal 2006, No. 69, item 625, as amended) [23].

At present, electricity in Poland from sources with a substitute is recommended through a tender system. Installations switched on before 1 July 2016 have the option of choosing between offers and the quota system. Enterprises that are required to provide electricity acquire so-called Certificates of Origin, which are given to producers of electricity from renewable sources. In addition, renewable electricity is supported by tax breaks and loan programs. [24].

Network operators are declared to connect renewable energy plants to their networks without harassing these generators. Network operators are required to take the primacy of electricity transmission from renewable sources and to develop the network in accordance with the general provisions of the energy law. In addition, installation operators are not competent to develop the network [25-27].

The existing local document, which currently helps us in planning the development of energy from renewable sources in the West Pomeranian Region, is Report. Potential and use of renewable energy sources in the production of electricity and heat in the West Pomeranian Region, issued by the Regional Spatial Planning Office of the West Pomeranian Region in November 2018 and the Energy Sector Development Program in the West Pomeranian Region until 2015, with a view to 2030. [28-31].

The Natura 2000 protected areas are a significant spatial limitation for the development of wind energy. This form of nature protection in Poland was introduced in 2004. Areas of the greatest importance for the conservation of endangered or very rare species of plants and animals or characteristic natural habitats of importance for the protection of the natural values of the whole of Europe are recognized as Natura 2000 areas. The method of protection within each of these areas may be different. A very important activity in relation to Natura 2000 areas is monitoring the status of natural habitats, habitats of plant and animal species and their populations within them, and reporting the results of these observations, as it enables the assessment of the effectiveness of conducted conservation activities [32]

In addition, a further limitation has been added from densely populated areas, where investments for wind energy purposes cannot be implemented or encounter significant inconveniences in practice [33-36].

The draft Polish energy policy presented on November 23, 2018, is a state strategy in the energy sector until 2040 (PEP2040) [37]. This strategy is the answer to which the Polish energy sector is today. This strategy sets directions for the development of the energy sector. The implementation of the 2040 Polish Energy Policy Project will be implemented through eight directions of activities in the energy sector, such as

(1) Optimal use of energy resources;

(2) Intensification of electricity production;

(3) Diversification of supplies of conventional energy sources; 
(4) Expansion of energy markets;

(5) Use of nuclear energy;

(6) Expansion of substitutes for conventional energy sources;

(7) Development of cogeneration;

(8) More effective energy improvement of the economy.

The Polish Energy Policy 2040 assumes that the share of renewable energy in heating and cooling will increase by about 1-1.3 percent annually. The use of energy from biomass and biogas, geothermal energy, heat pumps, and solar energy will contribute to the production of renewable energy in this subsector, while for electricity it will be solar, offshore and offshore wind energy, energy from biomass and biogas, and hydropower. The 2040 Polish Energy Policy assumes, among others, that:

- Poland will, to some extent, contribute to the achievement of the EU-wide renewable energy target for 2030 which does not threaten the energy security of the state. The share of renewable energy sources in final energy consumption will be about $21 \%$ in 2030 . It will result from cost efficiency and the possibility of balancing energy in the National Energy Network.

- The adopted target of $21 \%$ share of renewable energy sources in gross final energy consumption in 2030. It will translate into an approximately $27 \%$ share of renewable energy sources in net electricity production and will require significant economic and organizational effort.

- The development of photovoltaics (especially from 2022) and offshore wind farms (the first offshore wind farm will be launched after 2025) will play a key role in achieving the goal in the power industry [38].

\section{The State of Renewable Energy and Available Potential in the West Pomeranian Region}

The West Pomeranian Region is one of the better located in relation to renewable energy resources in Poland. Areas located on the seashore, i.e., the northern part of the province, have extremely favourable conditions for the location of wind installations. Areas located in the eastern part of the province have the possibility of using geothermal waters with high temperatures above $80^{\circ} \mathrm{C}$. Heat pumps can be used throughout the entire voivodship. The agricultural and forestry character of a large part of the province gives the opportunity to use a significant amount of biomass for energy purposes. The western part of the voivodship is one of the areas where the highest insolation occurs in Poland-over 1620 hours per year [23].

The weakest side of the voivodship's energy system in terms of the use of renewable energy is the significant degree of depletion of the Medium Voltage network, which due to age and failure to meet new needs, makes it difficult to connect new renewable energy sources. The system must also be adapted to the possibility of sending surplus production to other provinces [23]. In Table 1, the use of renewable energy sources in the West Pomeranian Region is provided.

Currently, the largest wind farms in the West Pomeranian Region are Karścino-Pobłocie in the commune. Karlino and Gościno (90 MW); Marszewo in Postomino (82 MW); Resko II in Łobez and Brzeżno (76 MW); Kozielice II in Pyrzyce (58 MW); Pieńkowo in the commune Postomino (54 MW); Kukinia in the commune Ustronie Morskie and Dygowo (52.9 MW); Karścino-Sarbia in Kołobrzeg (51 MW); Bardy in gm. Dygowo, Kozielice I in commune Pyrzyce; Tychowo in Sławno and Tymień in the commune Bedzino (all 50 MW each), Wysoka II in the commune Boleszkowice (40 MW); Tychowo in Stargard (34.5 MW), Jagniatkowo in the commune Wolin (30.6 MW), Kamionka in the commune Mieszkowice, Śniatowo in the commune Kamień Pomorski; Wartkowo in the commune Gościno, Zagórze in the commune Wolin and Skrobotowo in Karnice (all 30 MW). The location of wind farms and wind farms in the West Pomeranian Region is illustrated in Figure 1 below [23]. 
Table 1. Installations of substitutes for conventional energy sources in the studied region.

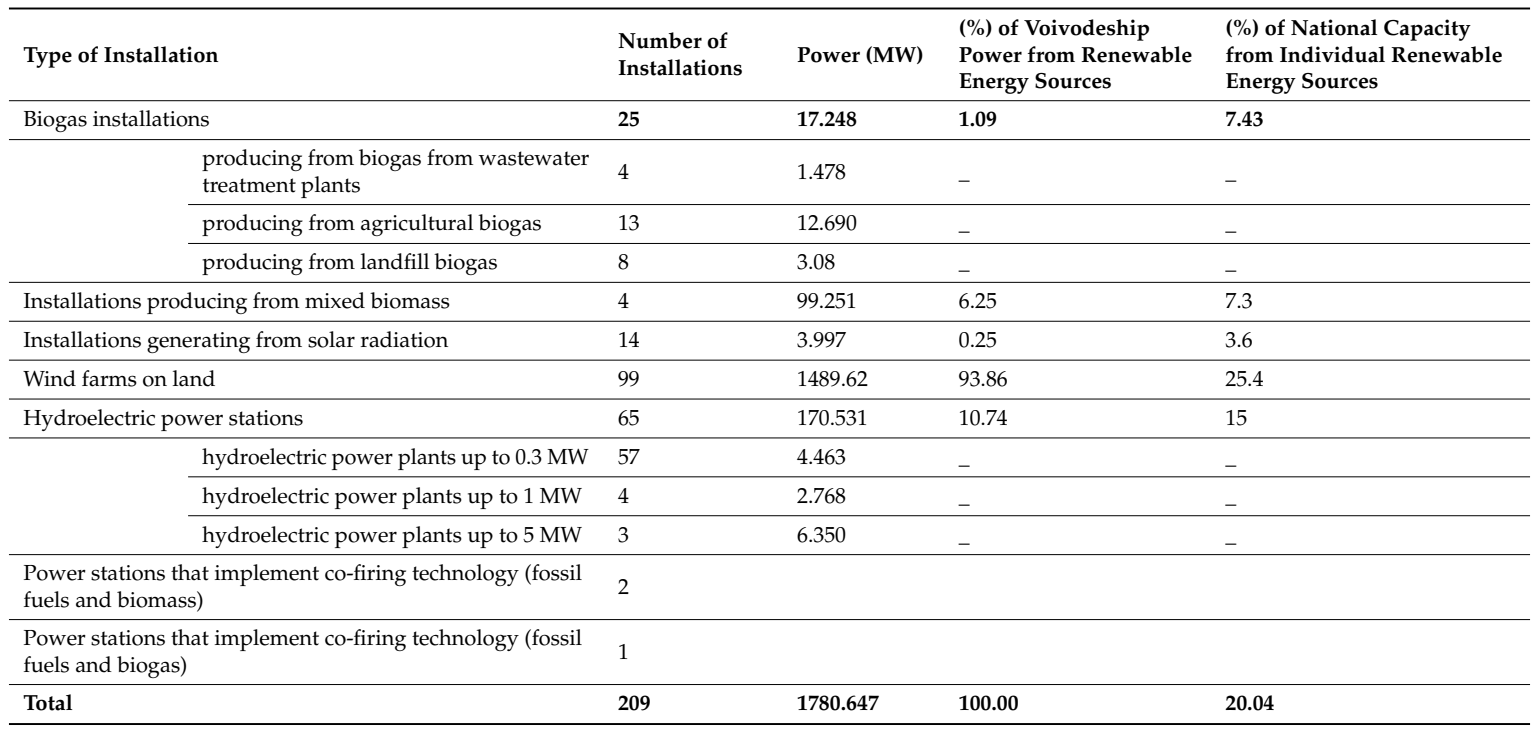

Source: based on the data of the Energy Regulatory Office-existing condition as at 31/03/2018.

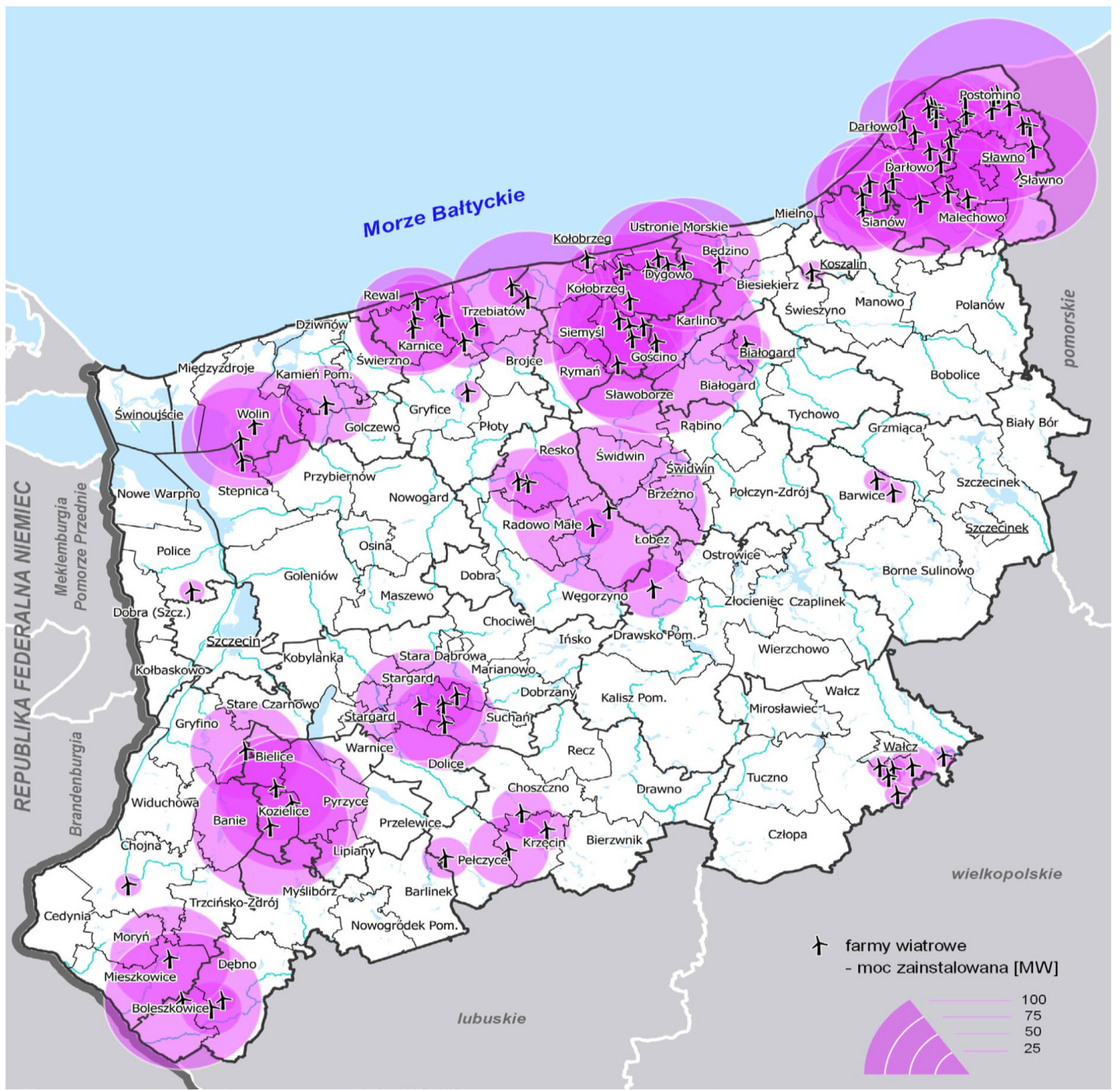

Figure 1. Location of wind farms in the West Pomeranian Region. (Source: Based on data from the Regional Bureau of Spatial Management of the West Pomeranian Region, as of 31/03/2018.) 
Wind energy efficiency is associated with the use of open areas. Currently, the area of arable land in the West Pomeranian Region is 95,421 billion square meters [23].

Based on the available data, it can be concluded that over $90 \%$ of the arable land in the West Pomeranian Region is suitable for technical use for the needs of wind energy. For further estimates, it was assumed that the demand for space in modern wind energy is 10 ha per $1 \mathrm{MW}$ of installed capacity (according to The European Wind Energy Association) [39].

The assumptions of the biomass potential in the West Pomeranian Region also include the Polish Energy Policy Project presented on November 23, 2018, until 2040, and the Polish Energy Policy project until 2050, presented on August 10, 2015, also takes into account the Natura 2000 protected areas which impose limitations for the development of wind energy. In addition, a further limitation has been added from densely populated areas, where investments for wind energy purposes cannot be implemented or encounter significant inconveniences in practice. In the West Pomeranian Region, $12.8 \%$ of arable lands are attractive areas for wind energy.

It is estimated that the potential of wind energy in the West Pomeranian Region, taking into account all environmental restrictions, is 12,200 MW. With the assumptions made, this would correspond to the production of $26.600 \mathrm{GWh}$ per year [23].

The Act of 20 May 2016 on investments in wind farms published in the Official Journal [40]. defines the conditions and procedures for the location and construction of wind farms. This Act contains provisions on the location of wind farms near actual or planned residential buildings. The Act introduces distance from protected areas, such as national parks, nature reserves, forest complexes, and Natura 2000 areas.

According to the act, the location of the wind farm is based only on the local spatial development plan, which sets out the distances from housing development and areas under nature protection. This distance should be equal to or greater than ten times the height of the wind farm. This structure should be measured from ground level to the highest point of the structure, together with the rotor and blades. In the province, except for a small southeastern part, there are sufficient wind conditions for the development of wind energy. The area in the coastal belt is characterized by very favourable conditions for the development of this type of energy. The obstacle to the development of wind installations in the region is the poor transmission capacity of power networks. The dimension of new investments in the West Pomeranian Region will clearly exceed real transmission capacity. Unrealized investments will block access to the network for investors [40]. Regulations for the location of wind farms:

(1) The location of a wind farm is only based on the local spatial development plan [41].

(2) The development of wind energy must be based on local planning guidelines, stating that the location of wind farms must respect the indications from a landscape study taking into account the scenic connections, especially with regard to natural and cultural protected areas, panoramas and viewpoints, foreground of exposure more of important communication routes, recreation areas in the coastal zone [42].

(3) The distance of the wind system from a residential building or multi-functional building, which includes a residential function, must be equal to or more than ten times the height of the wind farm.

(4) The distance referred to above is also required for the location and construction of a wind farm in the vicinity of areas covered by forms of nature protection, such as national parks, nature reserves, landscape parks, Natura 2000 areas, and in the vicinity of forest promotional complexes.

(5) At the location of a wind farm, protective zones of appropriate width should be maintained from forest areas, waters, roads, railways, technical infrastructure facilities, existing wind farms [38].

The location of the wind farm in accordance with the Act results from the local spatial development plan and from a distance of ten times the distance from residential buildings and areas covered by forms of nature protection. Wind farms that obtained building permits before the act entered into force were exempted from the new requirements [40]. 
Pursuant to the Act of 20 May 2016 on investments in wind farms, the average height of implemented wind farms in the West Pomeranian Region was assumed to be about $150 \mathrm{~m}$ (in the highest rotor position), which gives the abovementioned location distance, required by law as $1500 \mathrm{~m}$. The analysis also took into account other restrictions for the development of wind energy (not specified in the act) together with buffers (protection zones):

- Natural areas:

- Forest areas-buffer $200 \mathrm{~m}$;

- Water-up to about 1 ha-buffer 100 m, above 1 ha-buffer 200 m, rivers-buffer 200 m;

- Seacoast belt-buffer $3 \mathrm{~km}$ from the baseline of the sea;

- Areas and infrastructure objects:

- Roads- buffer $100 \mathrm{~m}$ per side from the road axis;

- Railway-buffer $100 \mathrm{~m}$ per page;

- Airports and raid zones-without a buffer;

- Overhead power lines-200 $\mathrm{m}$ buffer per side from the line axis;

- Radio links-30 m buffer per side from the radio station axis;

- Oil pipeline-buffer $50 \mathrm{~m}$ per side from the axis;

- Closed areas + protection zone;

- Zones from housing development located in the areas of neighbouring voivodships;

- Areas of existing wind farms-buffer $300 \mathrm{~m}$ [38].

The analysis of the potential shows that from the area of approximately 58,000 ha of local plans for the location of wind farms, only about 350 ha meets the statutory requirements, which gives a potential of about $35 \mathrm{MW}$ ( $84 \mathrm{GWh}$ ). It has a general potential of $300 \mathrm{MW}$ (729 GWh) to $360 \mathrm{MW}$ (874.8 GWh). It should be emphasized here that such a determined potential does not take into account infrastructural conditions and economic justification for the location of such dispersed devices.

\section{Wind Energy Model Assumptions}

Energy consumption in a given region is influenced by many factors, such as population, energy imports, energy exports, employment, industrial production, and technology development. [43,44]. Since the early 1970s, certain energy demand forecasting methods have been used to build the model. We can divide these methods into two categories. The first category is a time series forecasting method that allows you to build a model that uses historical energy consumption data. The second category is the impact of a multifactorial forecasting method, which estimates the energy consumption of the model [45].

The model's task is to provide a simplified but transparent picture of reality, ensuring its use in changing conditions, i.e., taking into account various aspects of the system, although they do not have to occur in all cases. Therefore, when planning energy production, it is necessary to resort to proven scientific methods. These include multi-criteria methods.

With the help of an optimizing multi-criteria model, a model was prepared that can be used to optimize the regional potential of wind energy. The authors' model takes into account, among others, legal acts, such as The Act on wind farms of 20 May 2016 and the Polish Energy Policy Project until 2040. An important factor shaping the energy balance of the West Pomeranian Region is the price of $\mathrm{CO}_{2}$ emission allowances-tightening the climate policy will lead to the need to invest in sources with lower carbon dioxide emissions.

The model also includes the price forecast for Carbon Emission Allowances (EUA) for 2021-2030.

The authors' model uses the lexicographic method, which allows finding the so-called compromize solution [46-49].The scope of empirical research was established for 2018-2030. The subject of the study is the West Pomeranian Region. 
The authors' model of intensifying renewable energy in the West Pomeranian Region was designed assuming the directions of the concepts included in the draft Polish energy policy until 2040. The most important strategic assumptions are:

- In 2030, Poland will achieve the share of renewable energy in final energy consumption—about $21 \%$. [50-52].

- The normative target of a $21 \%$ share of renewable energy in final gross energy consumption in 2030. This is about $27 \%$ of the renewable energy share in net electricity production. This increase will force a large economic and organizational effort.

- The intensification of solar farms and offshore wind farms will have a priority responsibility in achieving the target in the energy sector.

The West Pomeranian Region, which is the subject of research, is uniquely determined to produce renewable energy sources, especially wind energy. Currently, the largest biomass boiler in the country (Elektrownia Szczecin) is located in the studied area. However, one should note that the administrative area of the West Pomeranian Region does not coincide with the energy region.

Forecast of electricity production in the West Pomeranian Region, according to the draft of Poland's Energy Policy by 2050, will increase by approximately 30\% in 2030, compared to 2015 (Table 2). It will be connected both with the economic development of the region and with shifting the demand for final energy from fossil fuels in the direction of electricity, resulting from the growing mechanization of industry and services, the spread of electric vehicles (plug-in hybrids), and the electrification of water heating and heat production process in many households using coal or gas to this end.

Table 2. Forecast of electricity production in a given area of GWh.

\begin{tabular}{ccccc}
\hline & $\mathbf{2 0 1 5}$ & $\mathbf{2 0 2 0}$ & $\mathbf{2 0 2 5}$ & $\mathbf{2 0 3 0}$ \\
\hline Energy production (GWh) & $10,015.6$ & $11,217.4$ & $11,908.5$ & $13,020.2$ \\
\hline Source: Polish Energy Policy until 2040, Ministry of Energy, Warsaw, 23/11/2018 [53].
\end{tabular}

There are two types of income support for energy being a substitute for conventional sources in the study area:

- Income from Certificates of Origin,

- Income from the sale of energy from substitutes for conventional sources.

Each technology of generating electricity with a substitute for conventional sources will give the system a different amount of energy per year. This is due to the fact that each installation works with nominal power. Therefore, the maximum power consumption coefficients were applied in the authors' model. In this way, we can compare different types of installations (Table 3).

Table 3. Maximum power consumption in various installations of substitutes for conventional energy sources.

\begin{tabular}{lcl}
\hline Title & Title GWh GWh & Coefficient of Use Maximum Power (\%) \\
\hline $\begin{array}{l}\text { Theoretical maximum energy } \\
\text { production for a 1 MW installation. }\end{array}$ & 8.76 & 100.0 \\
\hline Solar installation. & 0.97 & 11.1 \\
\hline Wind farm installation & 2.10 & 24.0 \\
\hline Biomass installation & 2.19 & 25.0 \\
\hline Water installation & $2 ., 7$ & 30.8 \\
\hline Biogas installation & 3.35 & 38.3 \\
\hline Waste installation & 2.75 & 31.5 \\
\hline Coal installation & 6.9 & 78.8 \\
\hline
\end{tabular}

Source: Szymański, B. How to Compare the Power of Renewable Energy Plants with Conventional Ones; Solaria: Warsaw, Poland, 2013 [54]. 
Due to the fact that the forecasts adopted an increasing pressure on the reduction in greenhouse gas emissions, an increasing path of prices for $\mathrm{CO}_{2}$ emission allowances was adopted [10,55-57]. Table 4 presents the forecast for prices for $\mathrm{CO}_{2}$ emission allowances (EUR'10/tCO $\mathrm{CO}_{2}$.

Table 4. Current price forecast for Carbon Emission Allowances (EUA) for 2021-2030.

\begin{tabular}{llllllllllll}
\hline Forecasts of EUA Prices & & & & & & & & & \\
\hline Year & $\mathbf{2 0 2 1}$ & $\mathbf{2 0 2 2}$ & $\mathbf{2 0 2 3}$ & $\mathbf{2 0 2 4}$ & $\mathbf{2 0 2 5}$ & $\mathbf{2 0 2 6}$ & $\mathbf{2 0 2 7}$ & $\mathbf{2 0 2 8}$ & $\mathbf{2 0 2 9}$ & $\mathbf{2 0 3 0}$ & $\mathbf{2 0 2 1 - 3 0}$ \\
\hline Nominal EUA price (€) & 23.7 & 23.7 & 23.3 & 22.8 & 22.2 & 21.7 & 20.9 & 22.1 & 23.8 & 26.2 & $\mathbf{2 3 . 0 4}$ \\
\hline Real EUA price (€) & 22.3 & 21.9 & 21.2 & 20.3 & 19.4 & 18.6 & 17.6 & 18.4 & 19.5 & 21.2 & $\mathbf{2 0 . 0 4}$ \\
\hline
\end{tabular}

Source: Own study based on the Thomson Reuters forecast dated October 16, 2018

It is forecast that in 2021-2027 prices will fall from 23.7 to 20.9 euros. Factors affecting this condition can be:

- Reduction in carbon dioxide emission rights resulting from the demand of electricity producers;

- Reduction in the coefficient determining the number of allowances in 2023 from $24 \%$ to $12 \%$.

- The impact of large allowance prices will encourage, at the end of the current period, the reduction in emissions by changing fuel.

It is expected that in 2028-2030 the price of carbon dioxide emission allowances will increase from 22.1 to 26.2 euros. The reason for the increase will be the accumulated surplus of carbon dioxide emission allowances. It is estimated that in reserve in 2030, there will be about 600 million EUA allowances. It is assumed that after 2030, the not very high number of $\mathrm{CO}_{2}$ emission allowances available on the market will result in the introduction of more radical climate goals. These goals force EU ETS participants to reduce emissions further. This change will also force additional purchases of allowances and contribute to the increase in prices of carbon dioxide emission allowances.

\section{Model of Wind Energy Use}

In the optimization model, technical and economic parameters were first calculated, and the minimum or maximum level of equilibrium conditions was established. Twenty-four decision variables were adopted in the authors' model.

The following decision variables have been applied to the model:

$x_{1}$-Generating non-renewable energy $(\mathrm{kWh})$;

$x_{2}$-Generating energy from co-firing $(\mathrm{kWh})$;

$x_{3}$-Generating water energy ( $\mathrm{kWh}$ ) from existing installations (until the end of 2017);

$x_{4}$-Hydropower generation (kWh) in new installations (from January 2018);

$x_{5}$ - Solar energy generation $(\mathrm{kWh})$;

$x_{6}$-Generating energy from windmills at domestic $(\mathrm{kWh})$;

$x_{7}$-Generating energy from wind farms (kWh) from existing installations (until the end of 2017);

$x_{8}$-Wind energy $(\mathrm{kWh})$ in new installations (from January 2018);

$x_{9}$-Generating energy from biogas $(\mathrm{kWh})$;

$x_{10}$-Generating energy from biogas in high-efficiency cogeneration with a total installed electrical capacity of less than $1 \mathrm{MW}$ in $(\mathrm{kWh})$;

$x_{11}$-Biogas energy generation $(\mathrm{kWh})$ in new installations (from January 2018);

$x_{12}$-Generating energy from biofuels $(\mathrm{kWh})$;

$x_{13}$-Generating energy from biomass combustion $(\mathrm{kWh})$ from existing boilers (until the end of 2017);

$x_{14}$-Energy generation from biomass combustion $(\mathrm{kWh})$ from new boiler installations (from January 2018);

$x_{15}$-Total annual electricity production from various energy sources $(\mathrm{kWh})$;

$x_{16}$-Crop size energy willow $(\mathrm{kWh})$; 
$x_{17}$-Size of miscatus crops (kWh);

$x_{18}$-Poplar crop size (kWh);

$x_{19}$-Size of sidaz crop $(\mathrm{kWh})$;

$x_{20}$-Jerusalem artichoke crop size $(\mathrm{kWh})$;

$\mathrm{x}_{21}$-Size of oilseed rape cultivated for biofuels $(\mathrm{kWh})$;

$x_{22}$ - Size of cereals cultivated for biofuels (kWh);

$x_{23}$-Size of corn grown for biogas $(\mathrm{kWh})$;

$x_{24}$-Size of beet crop for biogas ( $\mathrm{kWh}$ ).

In the authors' model, the objective function includes production costs, EUA allowance prices together with ecological costs, certificates for all types of energy (variables from $x_{1}$ to $x_{14}$ ) and loss of fertility, biogas, biofuels, and agricultural production (variables from $x_{16}$ to $x_{24}$ )

The objective function (minimized) consisted of four elements:

- Costs related to energy production;

- Costs associated with the prices of certificates;

- $\quad$ EUA dependent costs

- Costs related to the decrease in soil fertility.

The optimization authors' model has minimized only one function $(\mathrm{L}(x))$, which was the content of the above elements. Pursuant to the Act of 20 May 2016 On Investments in Wind Farms, the volume of wind energy production may increase by $35 \mathrm{MW}(84 \mathrm{GWh})$. The demand for electricity is projected to increase by around 55\% in 2030 compared to 2006. In 2030, the cost of EUA allowances is forecast to be EUR 23.04, or 0.14 PLN per kWh. In 2030, energy production will amount to 11,956.08 GWh (Table 5).

Table 5. Electricity production forecast for the area under investigation until 2030.

\begin{tabular}{ll}
\hline $\begin{array}{l}\text { Energy Production in } 2006 \text { in Installations Located } \\
\text { in the West Pomeranian Region (GWh) }\end{array}$ & $\begin{array}{l}\text { Energy Production in } 2030 \text { in Installations Located } \\
\text { in the West Pomeranian Region (GWh) }\end{array}$ \\
\hline 7713.6 & $11,956.08$ \\
\hline
\end{tabular}

Source: Polish Energy Policy until 2040, Ministry of Energy, Warsaw, 23/11/2018 [53].

The model assumes that in 2030 the cost of generating kWh of energy will increase by $160 \%$ compared to 2019. Therefore, taking into account the cost of electricity generation, we can estimate the cost parameters. The cost parameters for each type of energy are shown in Table 6.

Table 6. The amount of the cost for each type of energy expressed in Polish currency.

\begin{tabular}{|c|c|c|c|c|c|c|c|c|c|c|c|c|c|c|}
\hline Types of Energy & $x_{1}$ & $x_{2}$ & $x_{3}$ & $x_{4}$ & $x_{5}$ & $x_{6}$ & $x_{7}$ & $x_{8}$ & $x_{9}$ & $x_{10}$ & $x_{11}$ & $x_{12}$ & $x_{13}$ & $x_{14}$ \\
\hline costs of production & 0.58 & 0.79 & 0.70 & 0.7 & 1.10 & 0.65 & 0.65 & 0.65 & 0.70 & 0.65 & 1.39 & 1.10 & 0.45 & 0.45 \\
\hline the cost of the certificate & 0.00388 & 0.00388 & 0.12385 & 0.12385 & 0.12385 & 0.12385 & 0.12385 & 0.2012 & 0.12385 & 0.12385 & 0.2012 & 0.12385 & 0.12385 & 0.2012 \\
\hline the cost of EUA & 0.14 & 0.14 & 0 & 0 & 0 & 0 & 0 & 0 & 0 & 0 & 0 & 0 & 0 & 0 \\
\hline total costs (PLN / kWh) & 0.69 & 0.90 & 0.57 & 0.57 & 0.97 & 0.52 & 0.52 & 0.44 & 0.56 & 0.51 & 1.17 & 0.96 & 0.32 & 0.24 \\
\hline
\end{tabular}

The costs associated with a decrease in fertility are shown in Table 7.

Table 7. Cost associated with a decrease in fertility (kWh/ha).

\begin{tabular}{cccccccccc}
\hline Energy Resources & $x_{16}$ & $x_{17}$ & $x_{18}$ & $x_{19}$ & $x_{20}$ & $x_{21}$ & $x_{22}$ & $x_{23}$ & $x_{24}$ \\
\hline $\begin{array}{l}\text { Costs associated with a } \\
\text { decrease in soil fertility }\end{array}$ & 0.32 & 0.32 & 0.32 & 0.32 & 0.32 & 0.12 & 0.12 & 0.26 & 0.26 \\
\hline
\end{tabular}


The following values are the average costs of generating kWh of energy from separate energy resources. These resources are shown in Table 8.

Table 8. Cost of energy production from power plants (in $\mathrm{kWh} / \mathrm{ha}$ ).

\begin{tabular}{cccccccccc}
\hline Energy resources & $x_{16}$ & $x_{17}$ & $x_{18}$ & $x_{19}$ & $X_{20}$ & $x_{21}$ & $x_{22}$ & $x_{23}$ & $x_{24}$ \\
\hline Production cost & 0.18 & 0.35 & 0.17 & 0.07 & 0.04 & 0.5 & 0.34 & 0.5 & 0.21 \\
\hline \multicolumn{10}{c}{ Source: Own study based on the model. }
\end{tabular}

The function of the authors' decision model is as follows:

$\mathrm{L}(x)=0.15 x_{1}+0.20 x_{2}+0.13 x_{3}+0.13 x_{4}+0.22 x_{5}+0.11 x_{6}+0.11 x_{7}+0.10 x_{8}+0.12 x_{9}+0.11 x_{10}+$ $0.27 x_{11}+0.22 x_{12}+0.07 \mathrm{x}_{13}+0.06 \mathrm{x}_{14}+0.32 \mathrm{x}_{16}+0.32 \mathrm{x}_{17}+0.32 \mathrm{x}_{18}+0.32 \mathrm{x}_{19}+0.32 x_{20}$

$+0.12 x_{21}+0.12 x_{22}+0.26 x_{23}+0.26 x_{24}-\min$

The side conditions are as follows:

The model assumes that all variables are non-negative.

$x_{1}+x_{2}+x_{3}+x_{4}+x_{5}+x_{6}+x_{7}+x_{8}+x_{9}+x_{10}+x_{11}+x_{12}+x_{13}+x_{14}=x_{15}$-total energy production. $x_{15} \geq 11,956,080,000 \mathrm{kWh}-$ energy production for the region.

$x_{3}+x_{4}+x_{5}+x_{6}+x_{7}+x_{8}+x_{9}+x_{10}+x_{11}+x_{12}+x_{13}+x_{14}=0.27 x_{15}$-renewable energy must account for $27 \%$ of the total energy production.

$x_{6}+x_{7}+x_{8} \geq 3,575,088,000 \mathrm{kWh}$-windmills must produce at least 3,575,088,000 kWh of energy.

$x_{8} \leq 84,000,000 \mathrm{kWh}$ - wind energy production in new installations from January 1, 2018

$x_{9}+x_{10} \geq 41,376,000 \mathrm{kWh}$-biogas combustion must produce at least $41,376,000 \mathrm{kWh}$ of energy.

$x_{13}+x_{14} \geq 238,200,000 \mathrm{kWh}$ - energy production from biomass burning.

$x_{9}+x_{10}=30,450,000 x_{23}+10,960,000 x_{24}$-energy production from biogas combustion.

$x_{11}+x_{12}=10,500 x_{21}+15,000 x_{22}$-production of energy from biofuel combustion.

$x_{13}+x_{14}=238,200,000 \mathrm{kWh}$-energy production from biomass combustion.

$x_{2} \leq 6,907,531,938 \mathrm{kWh}-$ maximum energy production from co-firing.

$x_{3}=409,270,000 \mathrm{kWh}$ - production of hydropower.

$x_{4} \geq 0 \mathrm{kWh}$-production of new hydropower

$x_{5} \geq 9,590,000 \mathrm{kWh}-$ minimal solar energy production.

\section{Discussion of Results}

The optimizing the model with this objective function gives the following solutions (Table 9).

Table 9. The results of optimization model.

\begin{tabular}{llllllllllllllll}
\hline Types of energy & $x_{1}$ & $x_{2}$ & $x_{3}$ & $x_{4}$ & $x_{5}$ & $x_{6}$ & $x_{7}$ & $x_{8}$ & $x_{9}$ & $x_{10}$ & $x_{11}$ & $x_{12}$ & $x_{13}$ & $x_{14}$ & $x_{15}$ \\
\hline Energy production & 0 & 7105.77 & 409.27 & 0 & 313.2 & 0 & 3575.08 & 82.50 & 30.45 & 10.96 & 25.25 & 0 & 238.20 & 165.40 & $11,956.08$ \\
\hline Energy raw materials & $x_{16}$ & $x_{17}$ & $x_{18}$ & $x_{19}$ & $x_{20}$ & $x_{21}$ & $x_{22}$ & $x_{23}$ & $x_{24}$ & & & & & \\
\hline Crop size & 0 & 0 & 0 & 0 & 0 & 0 & 0 & 0.042 & 0 \\
\hline \multicolumn{10}{c}{ Source: Own study based on the model. }
\end{tabular}

Analysing the obtained data from the model, it can be stated that in 2030, total energy production in the West Pomeranian Region will be 11,956.08 GWh. The model shows that the production of energy from co-firing in 2030 will be at the level of $7105.77 \mathrm{GWh}$. On the other hand, hydropower generated in hydropower plants created until December 31, 2018, will amount to 409.27 GWh.

Model calculations indicate that $303.64 \mathrm{GWh}$ will be generated in new solar installations by 2030 . At the end of 2018, however, solar energy production was $9.56 \mathrm{GWh}$. Total solar energy production in 2030 will be $313.2 \mathrm{GWh}$.

Model calculations indicate that, at the end of 2018, 3575.08 GWh of wind energy was generated in the region. By 2030, $82.50 \mathrm{GWh}$ will be generated at new wind farms. At the end of 2018, energy production from gas obtained from biomass, in particular from animal or plant waste treatment installations, sewage treatment plants, and waste landfills, will amount to $30.45 \mathrm{GWh}$. However, 
energy from biogas in high-efficiency cogeneration with a total installed electrical capacity below $1 \mathrm{MW}$ will amount to $10.96 \mathrm{GWh}$ in the region. Twenty-five point two five gigawatt-hours will be generated in new installations producing energy from biogas by 2030.

In 2018, the amount of energy produced in existing biomass boilers in the region was $238.20 \mathrm{GWh}$. Model calculations show that by 2030 new biomass installations in the region will be $165.40 \mathrm{GWh}$ produced. The average cost of building one MW of energy in the West Pomeranian Region will be $€$ $2,250,066$. Analysing the obtained soil fertility structure, it can be stated that the loss of soil fertility will be up to $0.059 \mathrm{t} / \mathrm{ha}$.

\section{Conclusions}

The regional energy planning model developed for the West Pomeranian region in this paper allows making forecasts on renewable energy development in the region by taking into account environmental and other legal regulations and their changes in Poland.

The modelling results reveal that the important factor for shaping the energy balance of the West Pomeranian Region is the price of $\mathrm{CO}_{2}$ emission allowances-tightening climate policy will lead to the need to invest in less-carbon sources, which, in its turn, will lead to a reduction in GHG emissions and required higher investment costs in the renewables.

The Act of 20 May 2016, on investments in wind farms has hindered the development of wind energy in Poland.

However, the expected high prices for $\mathrm{CO}_{2}$ emission allowances will decide on the profitability of replacing coal-fired units with new high-efficiency units, the scale of the RES share increase, as well as competitiveness of the renewable energy overall.

The role of wind energy will depend on its achievement of economic competitiveness in comparison with other energy production technologies in the light of increased high prices for $\mathrm{CO}_{2}$ emissions.

According to the Polish Energy Policy Project until 2040, the needed share of renewable energy in the total electricity production $(27 \%)$ in the West Pomeranian Region is expected to be achieved by 2030, and the regional energy planning model provides the means of how to achieve this.

Due to the increasing share of renewable energy in the West Pomeranian Region, the development of transmission and distribution infrastructure will also be necessary, and local government should raise investments for this purpose.

Author Contributions: The authors contributed equally to the work presented in this article. Conceptualization, M.R., D.S., and Y.B.; methodology, M.R.; validation, D.S., Y.B.; formal analysis, M.R., D.S., and Y.B.; writing—original draft preparation, M.R., D.S., and Y.B.; writing—review and editing, D.S., Y.B.; visualization, M.R. All authors have read and agreed to the published version of the manuscript.

Funding: This research received no external funding.

Conflicts of Interest: The authors declare no conflict of interest.

\section{References}

1. Anwar, A.; Arshed, N.; Kousar, N. Renewable Energy Consumption and Economic Growth in Member of OIC Countries. Eur. Online J. Nat. Soc. Sci. 2017, 6, 111-112.

2. Iorio, M.; Monni, S.; Brollo, B. The Brazilian Amazon: A resource curse or renewed colonialism? Entrep. Sustain. Issues 2018, 5, 438-451. [CrossRef]

3. Shakhovskaya, L.; Petrenko, E.; Dzhindzholia, A.; Timonina, V. Market peculiarities of natural gass: Case of the Pacific Region. Entrep. Sustain. Issues 2018, 5, 555-564. [CrossRef]

4. Rezk, M.R.; Radwan, A.; Salem, N.M.; Sakr, T.M.; Tvaronavičienė, M. Foresight for sustainable energy policy in Egypt: Results from a Delphi survey. Insights Reg. Dev. 2019, 1, 357-369. [CrossRef]

5. Bilan, Y.; Streimikiene, D.; Vasylieva, T.; Lyulyov, O.; Pimonenko, T.; Pavlyk, A. Linking between Renewable Energy, $\mathrm{CO}_{2}$ Emissions, and Economic Growth: Challenges for Candidates and Potential Candidates for the EU Membership. Sustainability 2019, 11, 1528. [CrossRef] 
6. Chen, J.; Cheng, S.; Nikic, V.; Song, M. Quo Vadis? Major Players in Global Coal Consumption and Emissions Reduction. Transform. Bus. Econ. 2018, 17, 112-133.

7. Moumen, Z.; El Idrissi, N.E.A.; Tvaronavičienè, M.; Lahrach, A. Water security and sustainable development. Insights Reg. Dev. 2019, 4, 301-317. [CrossRef]

8. Sarma, U.; Karnitis, G.; Zuters, J.; Karnitis, E. District heating networks: Enhancement of the efficiency. Insights Reg. Dev. 2019, 1, 200-213. [CrossRef]

9. Liao, H.; Long, Y.; Ming, T.; Mardani, A.; Xu, J. Low carbon supplier selection using a hesitant fuzzy linguistic span method integrating the analytic network. Transform. Bussiness Econ. 2019, 18, 67-88.

10. Brożyna, J.; Mentel, G.; Szetela, B. Renewable Energy and Economic Development in the European Union. Acta Polytech. Hung. 2017, 14, 11-34. [CrossRef]

11. Lavrinenko, O.; Ignatjeva, S.; Ohotina, A.; Rybalkin, O.; Lazdans, D. The Role of Green Economy in Sustainable Development (Case Study: The EU States). Entrep. Sustain. Issues 2019, 6, 1013-1026. [CrossRef]

12. Cherchyk, L.; Shershun, M.; Khumarova, N.; Mykytyn, T.; Cherchyk, A. Assessment of forest enterprises' performance: Integrating economic security and ecological impact. Entrep. Sustain. Issues 2019, 6, 1784-1797. [CrossRef]

13. Cucchiella, F.; D'Adamo, I.; Gastaldi, M.; Miliacca, M. Efficiency and allocation of emission allowances and energy consumption over more sustainable European economies. J. Clean. Prod. 2018, 182, 805-817. [CrossRef]

14. Tvaronavičienė, M.; Nesterova, K.; Kovacik, V. Energy security and long-term energy efficiency: Case of selected counties. J. Secur. Sustain. Issues 2017, 7, 349-357. [CrossRef]

15. Act of 10.04.1997, Energy Law, Journal of Laws No. 54 item 348. Available online: http://prawo.sejm.gov.pl/ isap.nsf/DocDetails.xsp?id=WDU19970540348 (accessed on 12 February 2020).

16. Szwed, P.; Barzyk, G. Economic Aspects of the Development of Wind Energy in Poland; "Czysta Energia"; Abrys: Poznan, Poland, 2008; p. 2.

17. Dudin, M.N.; Frolova, E.E.; Protopopova, O.V.; Mamedov, A.A.; Odintsov, S.V. Study of innovative technologies in the energy industry: Nontraditional and renewable energy sources. Entrep. Sustain. Issues 2019, 6, 1704-1713. [CrossRef]

18. Vlasov, A.I.; Shakhnov, V.A.; Filin, S.S.; Krivoshein, A.I. Sustainable energy systems in the digital economy: Concept of smart machines. Entrep. Sustain. Issues 2019, 6, 1975-1986. [CrossRef]

19. Rogalev, A.; Komarov, I.; Kindra, V.; Zlyvk, O. Entrepreneurial assessment of sustainable development technologies for power energy sector. Enterp. Sustain. Issues 2018, 6, 429-445. [CrossRef]

20. Savitz, R.; Gavriletea, M.D. Climate Change and Insurance. Transform. Bus. Econ. 2019, 18, $21-43$.

21. Collins, S.; Deane, J.P.; Ó Gallachóir, B. Adding value to EU energy policy analysis using a multi-model approach with an EU-28 electricity dispatch model. Energy 2017, 130, 433-447. [CrossRef]

22. Blazejczak, J.; Braun, F.G.; Edler, D.; Schill, W.-P. Economic effects of renewable energy expansion: A model-based analysis for Germany. Renew. Sustain. Energy Rev. 2014, 40, 1070-1080. [CrossRef]

23. Institute for Renewable Energy. Potential of Wind Energy and Biomass in the West Pomeranian Voivodeship until 2020/2030; Institute for Renewable Energy: Warsaw, Poland, 2011; p. 2.

24. Rzepa, J. Potential resources and possibilities of using energy biomass for biogas production in the Zachodniopomorskie Voivodship. In Regional and Local Energy Biomass Potential; Jasiulewicz, M., Ed.; Publishers of Koszalin University of Technology: Koszalin, Poland, 2018; p. 59.

25. Ciupuliga, A.R.; Cuppen, E. The role of dialogue in fostering acceptance of transmission lines: The case of a France-Spain interconnection project. Energy Policy 2013, 60, 224-233. [CrossRef]

26. Bednarek-Szczepańska, M. Wind energy as a subject of location conflicts in Poland. Energy Policy 2016, 19, 53-72.

27. Kuźniewski, M. Wind Generation-An Energy Roller Coaster and Ways to Tame It; WSIZiA: Warsaw, Poland, 2016; p. 158.

28. Maciej, J.; Nowak, J. Analysis of the Project Study on the Potential and Development of Renewable Energy Sources in the West Pomeranian Region; Regional Office for Spatial Planning of the West Pomeranian Region: Szczecin, Poland, 2017; pp. 15-28.

29. Regional Office for Spatial Management of the West Pomeranian Region. Potential and Use of Renewable Energy Sources in the Production of Electricity and Heat in the West Pomeranian Region; Regional Office for Spatial Management of the West Pomeranian Region: Szczecin, Poland, 2018; pp. 36-60. 
30. Rabe, M. Analysis of the Current Formal and Legal Situation and Market Conditions and Technical Conditions in Terms of the Use and Development of Renewable Energy Sources in the West Pomeranian Voivodeship; Regional Office for Spatial Planning of the West Pomeranian Region: Szczecin, Poland, 2017; pp. 3-37.

31. Płocharski, M. Use of Renewable Energy Sources in Heating-Elaboration for the Needs of the Report on the Condition, Legal and Economic Conditions and Prospects for the Development of Renewable Energy Sources in the West Pomeranian Region; Regional Office for Spatial Planning of the West Pomeranian Region: Szczecin, Poland, 2017; pp. 24-35.

32. Haładyj, A.; Kamieniecka, J.; Sienkiewicz, B.; Wójcik, B. Natura 2000 in School Education; Institute for Sustainable Development: Winnipeg, MB, Canada, 2007; pp. 33-34.

33. Brożyna, J.; Mentel, G.; Ivanová, E.; Sorokin, G. Classification of Renewable Sources of Electricity in the Context of Sustainable Development of the New EU Member States. Energies 2019, 12, 2271. [CrossRef]

34. Jankowiak, A.H. Cluster Policy Models in the VISEGRAD Group Countries-A Comparative Study. Transform. Bus. Econ. 2018, 17, 447-465.

35. Chilvers, J.; Pallett, H.; Hargreaves, T. Ecologies of participation in sociotechnical change: The case of energy system transitions. Energy Res. Soc. Sci. 2018, 42, 199-210. [CrossRef]

36. Späth, L.; Scolobig, A. Stakeholder empowerment through participatory planning practices: The case of electricity transmission lines in France and Norway. Energy Res. Soc. Sci. 2018, 23, 189-198. [CrossRef]

37. Sobolewski, J. The Energy Policy of Poland until 2040 (PEP2040); Ministry of Energy: Warsaw, Poland, 2018; pp. 27-38.

38. Kotowicz, J.; Kwiatek, B. Analiza potencjału wytwórczego farmy wiatrowej (Analisis of wind farm production potential). Rynek Energii 2019, 4, 38-47.

39. Environmental and Energy Study Institute. Offshore Wind Energy; Environmental and Energy Study Institute: Washington, DC, USA, 2010.

40. The Act of May 20. 2016 on In the Scope of Wind Farms, published in Journal of Laws of 2016 item 96. Available online: http://prawo.sejm.gov.pl/isap.nsf/DocDetails.xsp?id=WDU20160000961 (accessed on 12 February 2020).

41. Strielkowski, W. Social and Economic Implications for the Smart Grids of the Future. Econ. Sociol. 2017, 10, 310-318. [CrossRef]

42. Kharlamova, G.; Nate, S.; Chernyak, O. Renewable energy and security for Ukraine: Challenge or smart way? J. Int. Stud. 2016, 9, 88-115. [CrossRef]

43. Raszkowski, A.; Bartniczak, B. Towards Sustainable Regional Development: Economy, Society, Environment, Good Governance Based on the Example of Polish Regions. Transform. Bus. Econ. 2018, 17, 225-245.

44. Rabe, M.; Streimikiene, D.; Bilan, Y. The Concept of Risk and Possibilities of Application of Mathematical Methods in Supporting Decision Making for Sustainable Energy Development. Sustainability 2019, 11, 1018. [CrossRef]

45. Zeng, Y.; Zeng, Y.; Choi, B.; Wang, L. Multifactor-influenced energy consumption forecasting using enhanced back-propagation neural network. Energy 2017, 127, 381-396. [CrossRef]

46. Miller, C.A.; Richter, J.; O'Leary, J. Socio-energy systems design: A policy framework for energy transitions. Energy Res. Soc. Sci. 2015, 6, 29-40. [CrossRef]

47. WindEurope. Annual Offshore Statistics; WindEurope: Brussels, Belgium, 2017; pp. 32-38.

48. Tvaronavičienè, M.; Prakapienè, D.; Garškaitè-Milvydienė, K.; Prakapas, R.; Nawrot, Ł. Energy Efficiency in the Long-Run in the Selected European Countries. Econ. Sociol. 2018, 11, 245-254. [CrossRef]

49. European Union. Directive 2009/28/EC of the European Parliament and of the Council of 23 April 2009 on the promotion of the use of energy from renewable sources and amending and subsequently repealing Directives 2001/77/EC and 2003/30/EC. Off. J. Eur. Union 2009, 140, 16-62.

50. Stavytskyy, A.; Kharlamova, G.; Giedraitis, V.; Šumskis, V. Estimating the interrelation between energy security and macroeconomic factors in European countries. J. Int. Stud. 2018, 11, 217-238. [CrossRef]

51. Shindina, T.; Streimikis, J.; Sukhareva, Y.; Nawrot, Ł. Social and Economic Properties of the Energy Markets. Econ. Sociol. 2018, 11, 334-344. [CrossRef]

52. Kasperowicz, R.; Pinczyński, M.; Khabdullin, A. Modeling the power of renewable energy sources in the context of classical electricity system transformation. J. Int. Stud. 2017, 10, 264-272. [CrossRef]

53. Ministry of Energy. Polish Energy Policy until 2040; Ministry of Energy: Warsaw, Poland, 2018. 
54. Szymański, B. How to Compare the Power of Renewable Energy Plants with Conventional Ones; Solaria: Warsaw, Poland, 2013.

55. Hnatyshyn, M. Decomposition analysis of the impact of economic growth on ammonia and nitrogen oxides emissions in the European Union. J. Int. Stud. 2018, 11, 201-209. [CrossRef]

56. Bilan, Y.; Gavurova, B.; Stanisław, G.; Tkacova, A. The Composite Coincident Indicator (CCI) for Business Cycles. Acta Polytech. Hung. 2017, 14, 71-90.

57. Magda, R.; Vasa, L. Economic aspects of natural resources and land usage. Folia Pomeranae Universitatis. Technol. Stetin. Oeconomica 2012, 69, 49-58. article distributed under the terms and conditions of the Creative Commons Attribution (CC BY) license (http://creativecommons.org/licenses/by/4.0/). 